DOI 10.37882/2223-2982.2021.03-2.34

\title{
СТРУКТУРНАЯ СИНОНИМИЯ ТЕРМИНОВ СФЕР ГЕНЕТИКИ И ГЕННОЙ ИНЖЕНЕРИИ В СОВРЕМЕННОМ АНГЛИЙСКОМ ЯЗЫКЕ
}

\section{STRUCTURAL SYNONYMY OF GENETICS AND GENETIC ENGINEERING TERMS IN THE MODERN ENGLISH LANGUAGE ${ }^{2}$}

\section{A. Razduyev \\ Z. Khakiyeva \\ P. Zekiyeva}

Summary: The article examines such a common linguistic phenomenon as synonymy drawing on the material of the English-language Genetics and Genetic Engineering terms. Despite the presence of a large number of synonyms of lexical units in the language as a whole, within the framework of terminology, synonymy is considered as a negative phenomenon, since an ideal term corresponds to one special notion. The aim of the work is to identify the features of structural synonymy of terms used in scientific and technical texts and discourse. Specific models of synonymic rows on the basis of the number of lexemes are considered. In the course of the work, it has been determined that polylexemic terminological units (terminological phrases) containing two or more components-terminological elements most often enter the paradigmatic relations of synonymy in the fields of Genetics and Genetic Engineering. The authors come to the conclusion about the importance of the process of formation of terms-synonyms, which contributes to the development of special knowledge in the spheres in question. The study of synonymy is important from the point of view of unification, harmonization and standardization of genetic terminology.

Keywords: synonymy, term, terminology, Genetics, Genetic Engineering, discourse, text.

\author{
Раздуев Алексей Валерьевич \\ К.филол.н., доцент, с.н.С., ФГБОУ ВО «Пятигорский \\ государственный университет» \\ arazduev@bk.ru \\ Хакиева Залиха Усмановна \\ К.филол.н., дочент, ФГБОУ ВО «Чеченский \\ государственный университет» \\ zalikha_khakieva@mail.ru \\ Зекиева Петимат Масудовна \\ К.филол.н., дочент, ФГБОУВО «Чеченский \\ государственный педагогический университет» \\ sekieva@mail.ru
}

Аннотация: В рамках статьи изучается такое распространенное языковое явление, как синонимия на материале англоязычных терминов сфер генетики и генной инженерии. Несмотря на присутствие большого числа синонимов лексических единиц в языке в целом, в рамках терминологии синонимия рассматривается как негативное явление, так как в идеале одному термину соответствует одно специальное понятие. Целью работы является выявление особенностей структурной синонимии терминов, употребляемых в научно-технических текстах и дискурсе. Рассматриваются конкретные модели синонимических рядов, базирующиеся на количестве лексем. В ходе работы определено, что в сферах генетики и генной инженерии наиболее часто в парадигматические отношения синонимии вступают полилексемные терминологические единицы (термины-словосочетания), содержащие два и более компонента-терминоэлемента. Авторы приходят к выводу о значимости процесса образования терминов-синонимов, который способствует развитию специального знания в анализируемых сфера. Изучение синонимии важно с точки зрения унификации, гармонизации и стандартизации генетической терминологии.

Ключевые слова: синонимия, термин, терминология, генетика, генная инженерия, дискурс, текст.

мета. В том, что касается терминологии, синонимия в ее рамках долгое время считалась негативным явлением. Традиционно применяемый список требований к термину как специальной единице включает пункт отсутствия у него синонимов в рамках терминологии одной сферы [Лотте, 1961: 7-35]. В теории один термин вербализует одно специальное понятие, но на практике - несколько или иное качество, свойство или характеристику предной стороны, стремлением избежать повторов одних и тех же лексических единиц в рамках коммуникации (как письменной, так и устной), а с другой - обозначить то

инонимия - это весьма распространенное явление в рамках лексики современного английского языка. Возникновение синонимов обусловлено, с од1 Исследование поддержано грантом Президента РФ (проект № 075-15-2019-347 «Деривационное, когнитивно-семан-
тическое и дискурсивное моделирование русско-, англо- и испаноязычной терминологии сфер генетики и генной инженерии:
источники возникновения терминов, история развития и современное состояние терминосистем»), ФГБОУ ВО «Пятигорский госу-
дарственный университет», науч. рук. - канд. филол. наук, доц., старший науч. сотр. А.В. Раздуев.
2 The research was supported by the Russian Federation President grant (project 75-15-2019-347 «Derivative, cognitive-semantic
and discursive modelling of the Russian, English and Spanish Genetics and Genetic Engineering terminology: the sources of terms, history
of development and current state of the terminological systems»), Pyatigorsk State University, scientific advisor - A.V. Razduyev, PhD in
Philology, Associate Professor, senior researcher. 
терминологических единиц могут выступать для обозначения одного и того же понятия [см. Гринев, 1993: 7678], образуя синонимичные пары или даже ряды: latent phage - vegetative phage (латентный фаг - вегетативный фаг); chromonema - genonema - gene string (хромонема генонема - генная цепочка). Особенно ярко синонимия терминов проявляется в различных специальных текстах и дискурсе. Интересной в лингвистическом плане с точки зрения парадигматических отношений выступает находящаяся на стадии становления англоязычная терминология сфер генетики и генной инженерии.

Целью исследования является анализ синонимических пар и рядов терминологических единиц сфер генетики и генной инженерии в современном английском языке, выделение структурных типов синонимов, построение моделей синонимических рядов и исчисление частотности употребления каждой модели в текстах и дискурсе. Материалом для исследования послужили англоязычные терминологические единицы генетической сферы общим объемом 500 единиц, отобранные методом сплошной выборки из различных печатных и электронных источников по соответствующей тематике и могущие иметь синонимы. Используемый комплексный метод исследования включает в себя метод сплошной выборки терминов, метод сопоставительного анализа, метод реконструкции структурно-словообразовательных моделей (моделей терминодеривации), методы компонентного и дефиниционного анализа, а также методы количественной и статистической обработки данных. В ходе исследования выделены структурные типы синонимов и построены конкретные модели синонимических рядов.

В результате анализа эмпирического (терминологического) материала было выявлено, что около 1/4 всех отобранных англоязычных терминов сфер генетики и генной инженерии могут иметь синонимы (500 терминологических единиц).

В структурном плане термины-синонимы можно разделить на монолексемные (однословные) и полилексемные (многословные, главным образом, двухкомпонентные, реже - трех- и более компонентные, термины-словосочетания) [см. Алборова, Раздуев, 2014; Раздуев, Симонова, Лазько, 2019; Симонова, 2018; Razduyev, Simonova, 2019 и др.]. В соответствии с количеством структурных компонентов выделяются следующие модели синонимических пар и рядов, которые мы сводим к следующим дихотомиям:

1. монолексемный (однословный) термин - монолексемный (однословный) термин;

2. монолексемный (однословный) термин - полилексемный (многословный) термин / термин-словосочетание;

3. полилексемный (многословный) термин - полилексемный (многословный) термин / термин-сло- восочетание - термин-словосочетание [см. также: Джасим Ареф, 2007]. Причем в рамках третьей группы количество слов-компонентов может как совпадать, так и разниться (например: Graves' disease - Basedow disease - Basedow-Graves disease toxic diffuse goiter / болезнь Грейвса - Базедова болезнь - болезнь Грейвса-Базедова - диффузный токсический зоб). Все три группы имеют различное терминологическое наполнение, в том числе в количественном плане. Рассмотрим каждую из групп подробнее.

Первая группа «монолексемный (однословный) термин - монолексемный (однословный) термин» является самой немногочисленной (163 пары синонимов, или 29,64\% выборки объемом 550 терминологических единиц). Приведем и проанализируем некоторые примеры: acroblast (акробласт) - acrosome (акросома), acrosome (акросома) - idiosome (идиосома), idiosome (идиосома) acroblast (акробласт), ageing (старение) - senescence (старение), adichogamy (гомогамия)-homogamy (гомогамия), allelism (аллелизм) - allelomorphism (аллеломорфизм), androgenesis (андрогенез) - etheogenesis (этеогенез, андрогенез), pangenesis (пангенез, пангенезис) - regeneration (регенерация), aptonuon (аптонуон) - aptogene (аптоген), aster (астер) - astrosphaera (астросфера), aster (астер) - astrocentre (астросфера), autosome (аутосома) - euchromosome (эухромосома), digenesis (чередование поколений) - heterogenesis (гетерогенез), autogamy (автогамия) - selffertilization (самооплодотворение), variability (вариабельность, изменчивость) - variation (изменчивость), breeding (скрещивание) - crossing (скрещивание), chromonema (хромонема) - genonema (генонема), selfing (самопроизводство) - self-reproduction (самопроизводство), proto-cell (протоклетка) - probiont (пробионт), proterogyny (протерогиния) - protogyny (протогиния), plastosome (ядрышко) - mitochondrion (митохондрий), plasmosome (ядрышко) - nucleolus (ядрышко), plasmacitoma (плазмацитома, миелома) - myeloma (миелома), planospore (планоспора) - zoospore (зооспора), photorecovery (фотореактивация) - photoreactivation (фотореактивация), conception (оплодотворение) - fertilization (оплодотворение), cytoblast (ядро) - nucleus (ядро), cytogene (цитоген, плазмоген) plasmagene (плазмоген), degeneracy (дегенерация) - degeneration (дегенерация), heterozygosity (гетерозиготия, гетерозиготность) - heterozygosis (гетерозиготия, гетерозиготность), homeorhesis (гомеорез, гомеорезис) - саnalization (гомеорез, канализированность), homogametes (гомогаметы) - isogametes (изогаметы), leukosis (лейкоз) leukemia (лейкемия), inductor (индуктор) - inducer (индуктор, эвокатор), infertility (бесплодность, стерильность) sterility (бесплодность, стерильность), inoculation (посев, инокуляция) - plating (посев), karyolymph (кариоплазма, кариолимфа, нуклеоплазма, ядерный сок) - karyoplasm (кариоплазма, кариолимфа, нуклеоплазма, ядерный сок) [Арефьев, Лисовенко, 1995; GMMG; GTBPG; Knapp, Knapp, 
2000; Lingvo; Multitran; NCIDGT; Thesaurus; TGGT] и дp.

Вторая группа «монолексемный (однословный) термин - полилексемный (многословный) термин / терминсловосочетание» является второй по численности (142 синонимичные пары, или 25,82\% терминологической выборки). Приведем некоторые примеры: Albers-Schoenberg disease (болезнь Альберса-Шенберга, мраморная болезнь костей) - osteopetrosis (остеопетроз, мраморная болезнь костей), Albright syndrome (синдром Олбрайта) - pseudohypoparathyroidism (псевдогипопаратиреоз, псевдогипопаратиреоидизм), Donohue syndrome (синдром Донахью) - leprechaunism (лепречаунизм), LouisBar syndrome (синдром Луи-Бар) - ataxia-teleangiectasia (атаксия-телеангиэктазия), Owren disease (болезнь Оврена) - parahemophilia (парагемофилия), bladder germ (бластула) - blastula (бластула), unisexual reproduction (однополое воспроизводство, партеногенез) - parthenogenesis (партеногенез), transgressive variation (трансгрессивная изменчивость) - transgression (трансгрессивная изменчивость), arrhenotokous parthenogenesis (арренотокный партеногенез) - arrhenotoky (арренотокия), breeding stock (стадо производителей) - broodstock (маточное стадо), bridge corpuscule (десмосома) - desmosome (десмосома), cell membrane (клеточная (плазматическая) мембрана, плазмалемма) - plasmalemma (плазмалемма), cell membrane (клеточная (плазматическая) мембрана) - cytolemma (плазмалемма), cell organ (органоид, органелла) - organelle (органелла), chromatic agglutination (слипание (хромосом), агглютинация хроматина) - stickiness (слипание (хромосом), агглютинация хроматина), chromosome pairing (синапсис, конъюгация хромосом) - synapsis (синапсис), coding triplet (кодон, триплет) - codon (кодон), complex mutation (комплексная мутация) - macromutation (макромутация), sublethal mutation (сублетальная мутация) - semi-lethal (полулетальная мутация, полулеталь), Scheie disease (болезнь Шейе) - gargoilism (гаргоилизм), random mating (случайное скрещивание, случайное спаривание, панмиксия) - panmixis (панмиксия), proteolytic enzyme (протеолитический фермент, протеаза, протеиназа) - peptidase (пептидаза), potency alleles (изоаллели) isoalleles (изоаллели), pollen mother cell (материнская клетка пыльцы) - microsporocyte (микроспороцит), permanent modification (длительная модификация, перманентная модификация) - daueromodification (перманентная модификация), egg cell (яйцеклетка) - ootid (оотид), elementary species (элементарный вид, биотип, геновид) - biotype (биотип, геновид), embryonic fission (дробление) - cleavage (дробление), monohybrid heterosis (моногибридный гетерозис) - overdominance (сверхдоминирование), еquational separation (эквационное деление) - postreduction (постредукция), equatorial nuclear plate (экваториальная ядерная пластинка) - mid-body (экваториальная ядерная пластинка), exaggeration gene (ген-интенсификатор, ген-усилитель) - intensifier (ген-интенсификатор, генусилитель), gene string (генонема, генная нить) - chro- monema (хромонема, генонема), modifying gene (генмодификатор) - modifier (ген-модификатор), maturation division (деление созревания) - meiosis (мейоз), insect pollination (энтомогамия, энтомофилия) - entomophily (энтомофилия), akaryote (безъядерная клетка) - enucleate cell (безъядерная клетка), allogamy (аллогамия, перекрестное оплодотворение, перекрестное опыление, чужеопыление) - open pollination (перекрестное оплодотворение, свободное опыление), intersterility (интерстерильность, гибридная стерильность) - hybrid sterility (гибридная стерильность), killer-factors (факторы-убийцы) - plasmid-like particles (плазмидоподобные частицы) [Арефьев, Лисовенко, 1995; GMMG; GTBPG; Knapp, Knapp, 2000; Lingvo; Multitran; NCIDGT; Thesaurus; TGGT] и др.

Третья группа «полилексемный (многословный) термин - полилексемный (многословный) термин / термин-словосочетание - термин-словосочетание» представляет собой наиболее объемную в количественном плане (245 синонимичных пар, или 44,55\% выборки). Рассмотрим некоторые примеры синонимических рядов, включающих двух-, трех-, четырех- и т.д. словные термины. Начнем с двухсловных синонимических соответствий: Aarskog syndrome (синдром Аарскога) - faciogenital dysplasia (фациогенитальная дисплазия, лице-генитальная дисплазия), cytogenic anemia (пернициозная анемия, злокачественная анемия) - Addison disease (болезнь Аддисона(-Бирмера)), bamboo hair (узловатая трихоклазия, расщепление волос) - Netherton syndrome (синдром Незертона), Haldane's law (правило Холдейна) - Haldane's rule (правило Холдейна), Barr body (тельце Барра) - sex chromatin (половой хроматин), Kanner syndrome (синдром Каннера) - infantile autism (детский аутизм), absolute lethal (полная леталь) - complete lethal (полная леталь), accidental hermaphroditism (случайный гермафродитизм) - developmental hermaphroditism (онтогенетический гермафродитизм), acentric chromosome (ацентрическая хромосома) - akinetic chromosome (акинетическая хромосома), allosteric enzyme (аллостерический фермент) - regulatory enzyme (регуляторный фермент), anucleate cell (безъядерная клетка) - enucleate cell (безъядерная клетка, цитопласт), uncycling cell (покоящаяся клетка) - resting cell (покоящаяся клетка, клетка в фазе), autoradiographic efficiency (авторадиографическая эффективность) - radioautographic efficiency (радиоавтографическая эффективность), blood coagulation (коагуляция крови, свертывание крови) - blood clotting (коагуляция крови, свертывание крови), breeding stock (маточное стадо, стадо производителей) - breeder's stock (маточное стадо, стадо производителей), breeding system (система скрещиваний) - mating system (система скрещиваний), cell strain (клеточный штамм) - cell line (клеточная линия), centric fission (отталкивание центромер) - centromere repulsion (отталкивание центромер), chromosome mottling (хромосомная эрозия) - chromosome erosion (хромосомная эрозия), chromosome phenotype (хромосомный фено- 
тип) - nuclear phenotype (ядерный фенотип), chromosome set (хромосомный набор) - chromosome complement (хромосомный набор), chromosome spiralization (спирализация хромосом) - chromosome condensation (конденсация хромосом, сокращение хромосом), cloning site (сайт клонирования, сайт встраивания) - insertion site (сайт встраивания), repressor gene (ген-репрессор, репрессивный ген) - regulator gene (ген-регулятор), repeated backcrossing (повторное бэккроссирование) - recurrent backcrossing (повторное бэккроссирование), recombination load (рекомбинационный груз) - segregational load (сегрегационный груз), recognition site (сайт распознавания, сайт узнавания) - restriction site (сайт рестрикции), recognition palindrome (короткий палиндром) - short palindrome (короткий палиндром), рорulation homeostasis (популяционный гомеостаз) - genetic homeostasis (генетический гомеостаз), pluriphasic lethal (многофазный летальный фактор) - polyphasic lethal (многофазный летальный фактор), pleuromitotic chromosome (плевромитотическая хромосома) - holocentric chromosome (голоцентрическая хромосома голокинетическая хромосома), constitutive immunity (конституциональный иммунитет) - natural immunity (естественный иммунитет, врожденный иммунитет), core structure (фибриллярный центр) - fibrillar center (фибриллярный центр), cross pollination (перекрестное оплодотворение, свободное опыление) - open pollination (перекрестное оплодотворение, свободное опыление), cross sterility (гибридная стерильность) - hybrid sterility (гибридная стерильность), cytoplasmic inheritance (материнское наследование) - maternal inheritance (материнское наследование), dark repair (темновая репарация) - dark reactivation (темновая репарация), dark repair (темновая репарация) - excision repair (эксцизионная репарация), deleterious mutation (вредная мутация) - detrimental mutation (вредная мутация), null allele (нулевой аллель) - silent allele (молчащий аллель), neutral equilibrium (пассивное равновесие) - passive equilibrium (пассивное равновесие), mutation frequency (частота мутаций) - mutation rate (частота мутаций), paracentromeric heterochromatin (прицентромерный гетерохроматин) - paracenric heterochromatin (прицентромерный гетерохроматин), concealed variability (скрытая изменчивость) - potential variability (потенциальная изменчивость), direct mutation (прямая мутация) - forward mutation (прямая мутация), distant hybridization (отдаленная гибридизация) - interspecific hybridization (межвидовая гибридизация), ectopic transcription (незаконная транскрипция) - illegitimate transcription (незаконная транскрипция), multiple genes (аддитивные факторы) - polymeric genes (полимерные гены), double exchange (двойной кроссинговер) - double crossing-over (двойной кроссинговер), multipolar mitosis (множественный митоз, многополюсный митоз, полицентрический митоз) - multipolar division (многополюсное деление, многополюсный митоз), multistrand model (полинемическая модель) - polynemic model (полинемическая модель), ethological isolation (этологическая изоляция) sexual isolation (половая изоляция), extraneous population (маргинальная популяция) - marginal population (маргинальная популяция), extranuclear inheritance (внеядерная наследственность) - maternal inheritance (материнское наследование), gene bank (банк генов) - genomic library (библиотека генов), genetic burden (генетический груз) - genetic load (генетическая нагрузка), genetic disease (генетическая болезнь) - hereditary disease (наследственная болезнь), genetic environment (генетическая среда) - genotypic environment (генотипическая среда), hereditary variation (наследственная изменчивость) - genetic variation (генетическая изменчивость), hermaphrodite flower (двуполый цветок) - bisexual flower (обоеполый цветок, двуполый цветок), latent phage (латентный фаг) - vegetative phage (вегетативный фаг), intrabreeding population (замкнутая популяция) - closed population (закрытая популяция), intragenic gene (внутригенный ген) - nested gene (внутригенный ген), intrasomatic selection (внутрисоматический отбор) - cell selection (клеточный отбор), invisible mutation (невидимая мутация) - silent mutation (молчащая мутация, мутация в неструктурном гене), isocoding mutation (изокодонная мутация) - samesence mutation (изокодонная мутация), isolation index (индекс изоляции) - isolation estimate (индекс изоляции), key gene (главный ген, олигоген, ключевой ген, основной ген) - major gene (главный ген, олигоген, ключевой ген, основной ген), colony hybridization (гибридизация колоний) - GrunsteinHogness method (метод Грюнштейна-Хогнесса), bifunctional vector (бифункциональный вектор) - dual-purpose plasmid (бифункциональный вектор), weak promotor («слабый» промотор) - low-level promotor («слабый» промотор) [Арефьев, Лисовенко, 1995; GMMG; GTBPG; Knapp, Knapp, 2000; Lingvo; Multitran; NCIDGT; Thesaurus; TGGT] и др.

Более редкими выступают синонимичные дихотомии с двух- и трехсловным соответствием, например: Krabbe disease (болезнь Краббе(-Бенеке)) - globioid cell leukodystrophy (болезнь Краббе), Angelman syndrome (синдром Ангельмана) - happy puppet syndrome (синдром счастливой куклы), Franklin syndrome (синдром Франклина) - heavy chain disease (болезнь тяжелых цепей), frameshift mutations (мутация «сдвига рамки» (считывания), мутация со сдвигом фазы) - reading frame mutations (мутация «сдвига рамки» (считывания), мутация со сдвигом фазы), chromosome pairing (синапсис, конъюгация хромосом) - conjugation of chromosomes (конъюгация хромосом), auxotrophic mutation (ауксотрофная мутация) - nutrient requiring mutation (ауксотрофная мутация), isopycnic centrifugation (изопикническое центрифугирование) - density gradient centrifugation (центрифугирование в градиенте плотности) [Арефьев, Лисовенко, 1995; GMMG; GTBPG; Knapp, Knapp, 2000; Lingvo; Multitran; NCIDGT; Thesaurus; TGGT] и др.

Другие полилексемные синонимичные соответствия еще меньше представлены в количественном плане, приведем некоторые примеры: asymmetric chromosome 
rearrangements (асимметричные перестройки хромосом) - asymmetric chromosome mutations (асимметричные мутации хромосом), giant platelet syndrome (синдром гигантских тромбоцитов) - Bernard-Soulier syndrome (синдром Бернара-Сулье), high-energy phosphate compound (высокоэнергетический фосфат) - energy-rich phosphate compound (высокоэнергетический фосфат), Maxam-Gilbert method (метод Максама-Гилберта) - chemical method of DNA sequencing (химический метод секвенирования ДНК), highly repetitious DNA (высокоповторяющаяся ДНК) - rapidly reassociating DNA (высокоповторяющаяся ДНК), passenger DNA (ДНК-пассажир) - cloned DNA (клонированная ДНК), junk DNA (избыточная ДНК, мусорная ДНК) - selfing DNA (избыточная ДНК), law of independence (закон независимого комбинирования признаков, третий закон Менделя) - law of independent assortment (закон независимого комбинирования признаков, третий закон Менделя), «island» model (модель «стога сена», модель локальной конкуренции за спаривание) - local mate competition model (модель локальной конкуренции за спаривание) [Арефьев, Лисовенко, 1995; GMMG; GTBPG; Knapp, Knapp, 2000; Lingvo; Multitran; NCIDGT; Thesaurus; TGGT] и др.

Соотношение всех трех групп структурных моделей терминов наглядно показано на диаграмме (см. Диаграмму 1).

\section{Синонимия англоязычных терминов сфер генетики и генной инженерии}

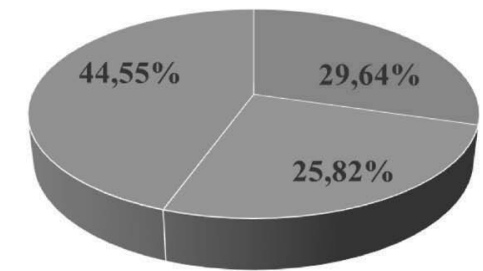

- Первая группа " Вторая группа = Третья группа

Диаграмма 1. Процентное соотношение моделей синонимических пар и рядов генетических терминов в структурном плане
В некотором смысле преобладание многокомпонентных англоязычных терминов в выборке, в целом, обусловливает тот факт, что в количественном отношении превалируют единицы третьей группы. Первая и вторая группы представлены приблизительно в равном соотношении, с небольшим количественным перевесом монолексемных пар синонимов (около 3\%), что может быть объяснено более длинными синонимичными рядами, которые составляют именно монолексемные терминологические единицы. Полилексемные соответствия представлены, главным образом, двусловными терминами. Следует отметить тот факт, что учет структурных особенностей терминов-синонимов важен в плане унификации, гармонизации и стандартизации англоязычной терминологии сфер генетики и генной инженерии, выборке терминологических единиц из синонимического ряда, разработке стандартов на термины и определения, а также в рамках учебных курсов для подготовки специалистов-генетиков и генных инженеров.

Таким образом, в результате анализа терминологической выборки мы приходим к выводу о том, что в структурном плане в рамках синонимии преобладает дихотомия «полилексемный (многословный) термин - полилексемный (многословный) термин / термин-словосочетание - термин-словосочетание» (245 синонимичных пар) по сравнению с комбинациями «монолексемный (однословный) термин - монолексемный (однословный) термин» (163 пары синонимов) и «монолексемный (однословный) термин - полилексемный (многословный) термин / термин-словосочетание» (142 синонимичные пары). Следует отметить, что в количественном плане преобладают пары двусловных синонимов. С практической точки зрения полученные результаты могут найти применение при унификации, гармонизации и стандартизации терминологии сфер генетики и генной инженерии современного английского языка, разработке соответствующих стандартов на термины и определения, а также при обучении специалистов-генетиков и генных инженеров.

1. Алборова А.А., Раздуев А.В. Структурные особенности гуманитарной и научно-производственной терминосистем в сопоставительном аспекте (на примере терминосистем киноиндустрии и нанотехнологий) // Вестник Брянского государственного университета. 2014. № 2. С. 306-312.

2. Арефьев В.А., Лисовенко Л.А. Англо-русский толковый словарь генетических терминов. М.: ВНИРО, 1995. 407 с.

3. Гринев С.В. Введение в терминоведение. М., 1993. 309 с.

4. Джасим Ареф М. Лингвистический термин в межкультурной коммуникации (к вопросу о принципах создания учебного словаря лингвистических терминов для иракских филологов-русистов) // Вестник Воронежского государственного университета. Серия: Лингвистика и межкультурная коммуникация. 2007. № 2. Ч. 1. С. 123-127.

5. Лотте Д.С. Основы построения научно-технической терминологии // Вопросы теории и методики. М.: Изд-во АН СССР, 1961. 160 с.

6. Раздуев А.В., Симонова Е.А., Лазько А.Ю. Основные морфологические и морфолого-синтаксические деривационные модели терминов сферы генетики (на материале английского языка) // Вестник Пятигорского государственного университета. 2019. № 3. С. 40-43. 
7. Симонова Е.А. Основные структурные типы английских, русских и испанских терминов сферы фармации // Вестник Пятигорского государственного университета. 2018. № 2. С. 198-205.

8. Genetic. Synonyms. Thesaurus.com. URL: https://www.thesaurus.com/browse/genetic (дата обращения 15.12.2020). - Thesaurus.

9. Glossary of Medical and Molecular Genetics. Atlas of Genetics and Cytogenetics in Oncology and Haematology. URL: http://atlasgeneticsoncology.org/Educ/ GlossaryID30028ES.html (дата обращения: 15.12.2020). - GMMG.

10. Glossary of Terms. Basic Principles of Genetics: An Introduction to Mendelian Genetics. URL: https://www2.palomar.edu/anthro/mendel/glossary.htm (дata 06ращения 15.12.2020). - GTBPG.

11. Knapp S.D., Knapp S.D. The contemporary thesaurus of search terms and synonyms: A guide for natural language computer searching. Phoenix, AZ: Oryx Press, $2000.656 \mathrm{p}$.

12. Lingvolive.com. URL: https://www.lingvolive.com/ (дата обращения: 15.12.2020). - Lingvo.

13. Multitran.com. URL: https://www.multitran.com/ (дата обращения: 15.12.2020). - Multitran.

14. NCI Dictionary of Genetics Terms. National Cancer Institute. URL: https://www.cancer.gov/publications/dictionaries/genetics-dictionary (дата обращения 15.12.2020). - NCIDGT.

15. Razduyev A.V., Simonova E.A. The specificity of term formation in the fields of genetics and genetic engineering (based on the material of the English, Spanish and Russian languages) // Филология: научные исследования. 2019. № 6. С. 182-193.

16. Talking Glossary of Genetic Terms. National Human Genome Research Institute. URL: https://www.genome.gov//genetics-glossary/ (дата обращения: 15.12.2020). - TGGT.

( Р Раздуев Алексей Валерьевич (arazduev@bk.ru), Хакиева Залиха Усмановна (zalikha_khakieva@mail.ru),

Зекиева Петимат Масудовна (sekieva@mail.ru).

Журнал «Современная наука: актуальные проблемы теории и практики»

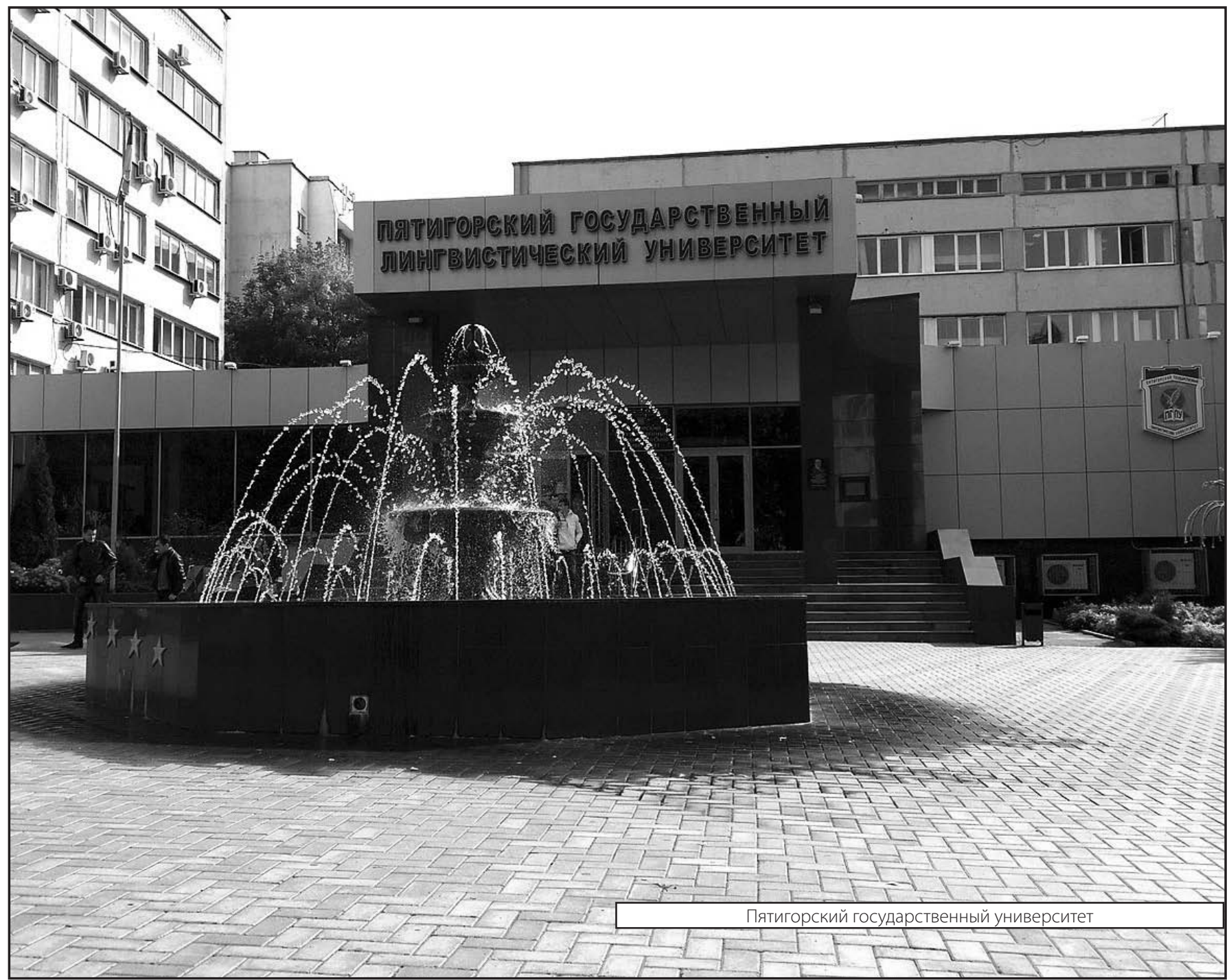

